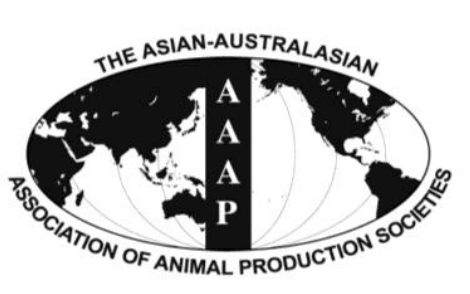

Open Access

Asian Australas. J. Anim. Sci.

Vol. 27, No. 6 : 855-861 June 2014

http://dx.doi.org/10.5713/ajas.2014.14006

www.ajas.info

pISSN 1011-2367 elSSN 1976-5517

\title{
Effects of Xylanase Supplementation on Growth Performance, Nutrient Digestibility and Non-starch Polysaccharide Degradation in Different Sections of the Gastrointestinal Tract of Broilers Fed Wheat-based Diets
}

\author{
L. Zhang, J. Xu, L. Lei, Y. Jiang ${ }^{1}$, F. Gao*, and G. H. Zhou \\ College of Animal Science and Technology, Synergetic Innovation Center of Food Safety and Nutrition, \\ Nanjing Agricultural University, Nanjing, 210095, China
}

\begin{abstract}
This experiment was performed to investigate the effects of exogenous xylanase supplementation on performance, nutrient digestibility and the degradation of non-starch polysaccharides (NSP) in different sections of the gastrointestinal tract (GIT) of broilers fed wheat-based diets. A total of 120 7-day-old Arbor Acres broiler chicks were randomly allotted to two wheat-based experimental diets supplemented with 0 or $1.0 \mathrm{~g} / \mathrm{kg}$ xylanase. Each treatment was composed of 6 replicates with 10 birds each. Diets were given to the birds from 7 to 21 days of age. The results showed that xylanase supplementation did not affect feed intake, but increased body weight gain of broiler at 21 day of age by $5.8 \%(\mathrm{p}<0.05)$ and improved feed-to-gain ratio by $5.0 \%$ (p<0.05). Xylanase significantly increased $(\mathrm{p}<0.05)$ ileal digestibilities of crude protein $(\mathrm{CP})$ by $3.5 \%$, starch by $9.3 \%$, soluble NSP by $43.9 \%$ and insoluble NSP by $42.2 \%$ relative to the control group, respectively. Also, compared with the control treatment, xylanase addition increased $(\mathrm{p}<0.05)$ total tract digestibilities of dry matter by $5.7 \%$, CP by $4.1 \%$, starch by $6.3 \%$, soluble NSP by $50.8 \%$, and had a tendency to increase $(\mathrm{p}=0.093)$ insoluble NSP by $19.9 \%$, respectively. The addition of xylanase increased the concentrations of arabinose and xylose in the digesta of gizzard, duodenum, jejunum, and ileum $(\mathrm{p}<0.05)$, and the order of their concentration was ileum $>$ jejunum $>$ duodenum $>>$ gizzard $>$ caecum. The supplementation of xylanse increased ileal isomaltriose concentration ( $p<0.05$ ), but did not affect the concentrations of isomaltose, panose and 1-kestose in the digesta of all GIT sections. These results suggest that supplementation of xylanase to wheat-based diets cuts the arabinoxylan backbone into small fragments (mainly arabinose and xylose) in the ileum, jejunum and duodenum, and enhances digestibilites of nutrients by decreasing digesta viscosity. The release of arabinose and xylose in the small intestine may also be the important contributors to the growth-promoting effect of xylanase in broilers fed wheatbased diets. (Key Words: Xylanase, Broiler, Performance, Digestibility, Non-starch Polysaccharide Degradation)
\end{abstract}

\section{INTRODUCTION}

In China, wheat has become an important source of energy in poultry diets because of a shortage of corn supply and the increase of corn price. However, the utilization efficiency of wheat is lower than that of corn because it

* Corresponding Author: F. Gao. Tel: +86-25-84399007, Fax: +86-25-84395314, E-mail: gaofeng0629@sina.com

${ }^{1}$ Ginling College, Nanjing Normal University, Nanjing 210097, China.

Submitted Jan. 3, 2014; Revised Jan. 29, 2014; Accepted Feb. 15, 2014 contains more anti-nutritive factors, especially non-starch polysaccharides (NSP). Arabinoxylans are the major NSP fractions in wheat, which increase digesta viscosity, reduce the digestibility of nutrients and decrease the feed efficiency and growth performance when fed to poultry, especially in broiler chickens (Choct and Annison, 1992a; Friesen et al., 1992). Moreover, dietary NSP can also accelerate small intestinal fermentation by modulating the intestinal microflora (Choct et al., 1996; Nian et al., 2011), which might be detrimental to nutrient digestion and absorption for chickens (Choct et al., 1999).

Nowadays, there is no doubt about the usefulness of

Copyright $@ 2014$ by Asian-Australasian Journal of Animal Sciences This is an open-access article distributed under the terms of the Creative Commons Attribution Non-Commercial License (http://creativecommons.org/licenses/by-nc/3.0/) which permits unrestricted non-commercial use, distribution, and reproduction in any medium, provided the original work is properly cited. 
exogenous microbial NSP-hydrolysing enzymes in wheatbased poultry diets. Xylanase has been widely added to commercial wheat-based compound feeds for broilers to overcome the anti-nutritional effects of NSP. Some previous studies have demonstrated that addition of xylanases in wheat-based diets can reduce the intestinal viscosity by partially hydrolyzing NSP of wheat, resulting in improvements in nutrient digestilities and growth performance of broilers (Choct et al., 2004; Gao et al., 2008; Vandeplas et al., 2010). Moreover, some other studies showed that xylanase supplementation of a wheat-based diet improved chicken immunity (Gao et al., 2007), reduced detrimental effect after Salmonella Typhimurium infection (Vandeplas et al., 2009), or alleviated the intestinal mucosal barrier impairment of broiler chickens challenged by Clostridium perfringens (Liu et al., 2012).

It is generally conceded that the beneficial effects of feed xylanase are primarily the reduction in the viscosity. The ability of xylanase to prevent the formation of viscous digesta appears to be the partial hydrolysis of NSP in the upper digestive tract, leading to a decrease of digesta viscosity in the small intestine (Bedford and Classen, 1992), and elimination of the nutrient encapsulating effect of the cell wall polysaccharides, and a release of the enclosed nutrients (Choct and Annison, 1992a; Meng et al., 2005). Gao et al. (2008) speculated that the growth-promoting effect of xlyanase may be also related to some oligosaccharides in the digesta of the gut produced by exogenous or endogenous enzymes. However, much less information is available on the effects of dietary xylanase supplementation on the NSP degradation and the release of some simple sugars and oligosaccharides in different sections of the gastrointestinal tract (GIT) of broilers fed wheat-based diets. Therefore, the objective of this study was to evaluate the effects of xylanase supplementation on growth performance, nutrient digestibilities, NSP degradation and the release of some simple sugars and oligosaccharides in different sections of the GIT of broilers fed wheat-based diets.

\section{MATERIALS AND METHODS}

\section{Enzyme preparation}

The enzyme supplement was provided by Jiahe Feed Biotechnology Co., Ltd, Hangzhou, China. The xylanase was derived from a genetically modified isolate of Aspergillus niger, consisting of 3,200 U/g enzyme activity determined using the 3,5-dinitrosalicylic acid reducing sugar method with oat xylan as substrate (Bailey, 1988). One unit of xylanase activity is defined as the amount of enzyme which, at $40^{\circ} \mathrm{C}, \mathrm{pH} 5.3$, liberates 1 mmole of reducing sugars (expressed as equivalents per min) from xylan.

\section{Birds, diets and experimental design}

A total of 200 1-day-old broiler chickens (Arbor Acres strain, AA) were purchased from a commercial hatchery (Hewei agricultural development Co., Ltd, Anhui, China). All chickens were fed a commercial broiler starter during the first 7 days. At the age of 7 day, 120 birds were selected by weight and randomly allotted to 2 wheat-based experimental diets supplemented with 0 or $1.0 \mathrm{~g} / \mathrm{kg}$ xylanase. The ingredient composition and nutrient levels of the basal diet are shown in Table 1. Each treatment group was composed of 6 replicates with 10 birds each (ten birds per cage). Diets were given to the birds from 7 to 21 days of age. The birds were kept in wired 3-level battery cages (75 $\mathrm{cm} \times 45 \mathrm{~cm}$ ) from 7 to 21 days and housed in an environmentally controlled room. The room was lit continuously during the whole experimental period and room temperature was controlled at $35^{\circ} \mathrm{C}$ from 0 to 3 day and then gradually reduced by $2^{\circ} \mathrm{C}$ to $3^{\circ} \mathrm{C}$ per week to a final temperature of $28^{\circ} \mathrm{C}$. Diets were fed in mash form and birds were allowed ad libitum access to feed and water. On

Table 1. The ingredient composition and nutrient levels of the basal diet to broilers

\begin{tabular}{|c|c|}
\hline Items & Starter (d 7-21) \\
\hline \multicolumn{2}{|l|}{ Ingredients (\%) } \\
\hline Wheat & 60.0 \\
\hline Corn & 7.5 \\
\hline Soybean meal & 28.0 \\
\hline Dicalcium phosphate & 1.35 \\
\hline Ground limestone & 1.41 \\
\hline Lysine-HCl & 0.26 \\
\hline DL-methionine & 0.11 \\
\hline Salt & 0.37 \\
\hline Premix $^{1}$ & 1.0 \\
\hline Total & 100 \\
\hline \multicolumn{2}{|l|}{ Nutrient levels (\%) } \\
\hline $\mathrm{ME}(\mathrm{MJ} / \mathrm{kg})$ & 12.2 \\
\hline $\mathrm{CP}$ & 21.6 \\
\hline Calcium & 1.0 \\
\hline Available phosphorus & 0.41 \\
\hline Lysine & 1.09 \\
\hline Methionine+cystine & 0.81 \\
\hline Soluble NSP ${ }^{2}$ & 1.9 \\
\hline Insoluble NSP ${ }^{2}$ & 8.36 \\
\hline Total NSP ${ }^{2}$ & 10.26 \\
\hline \multicolumn{2}{|c|}{$\begin{array}{l}\text { ME, metabolizable energy; } \mathrm{CP} \text {, crude protein; NSP, non-starch } \\
\text { polysaccharides. } \\
{ }^{1} \text { Premix provided per kilogram of diet: retinyl acetate, } 12,000 \mathrm{IU} \text {; } \\
\text { cholecalciferol, 2,500 IU; DL- } \alpha \text {-tocopheryl acetate, } 20 \mathrm{mg} \text {; thiamin } \\
\text { mononitrate, } 2 \mathrm{mg} \text {; riboflavin, } 6 \mathrm{mg} \text {; cyanocobalamin, } 0.025 \mathrm{mg} \text {; biotin, } \\
0.03 \mathrm{mg} \text {; folic acid, } 1.5 \mathrm{mg} \text {; calcium pantothenate, } 12 \mathrm{mg} \text {; nicotinic acid, } \\
50 \mathrm{mg} \text {; pyridoxine, } 5 \mathrm{mg} \text {; choline chloride, } 500 \mathrm{mg} \text {; iron, } 80 \mathrm{mg} \text {; copper, } \\
8 \mathrm{mg} \text {; manganese, } 100 \mathrm{mg} \text {; zinc, } 75 \mathrm{mg} \text {; iodine, } 0.35 \mathrm{mg} \text {; selenium, } 0.15 \\
\mathrm{mg} \text {. } \\
{ }^{2} \text { Analyzed value. }\end{array}$} \\
\hline
\end{tabular}


day 21 , body weight (BW) was recorded for each replicate, and feed consumption was also recorded. The body weight gain (BWG), feed intake, and feed conversion ratio (FCR; feed:gain, g:g) were calculated. All experimental procedures were approved by the Institutional Animal Care and Use Committee of Nanjing Agricultural University.

\section{Samples collection}

On the last 3 days of the experiment (on day 19 to 21), mixed excreta samples from each cage were total collected. The excreta samples were then dried at $60^{\circ} \mathrm{C}$ and finally ground for chemical analyses.

At the age of 21 days, 12 birds ( 2 birds per replicate) were randomly selected and killed by cervical dislocation. The body cavity was opened and the GIT was removed and ligated into eight segments: crop, proventriculus, gizzard, duodenum, jejunum (from duodenum to the Meckel's diverticulum), ileum (from the Meckel's diverticulum to 1 $\mathrm{cm}$ above the ileo-caecal junction), caecum and colon. The GI tract sections were squeezed lightly by hand and the digesta samples were collected. The digesta samples from the 2 birds within a cage were pooled in sealed bags and stored at $-20^{\circ} \mathrm{C}$ for the analyses of the monosaccharides and oligosaccharides. A subsample of the ileal digesta was dried at $60^{\circ} \mathrm{C}$ and ground for chemical analyses.

\section{Chemical analysis and calculations}

Diet, digesta and excreta samples were analyzed for the contents of dry matter (DM), crude protein (CP), fat, and ash using the AOAC procedures (2000). Starch content was measured based on the amyloglucosidase- $\alpha$-amylase method as described by McCleary et al. (1997). The soluble and insoluble NSP contents of diet, ileal digesta and excreta were determined according to the methods described by Englyst et al. (1994) and Quigley et al. (1999). Acidinsoluble ash (AIA) was determined as an indigestible marker following the method described by Vogtmann et al. (1975) and Choct and Annison (1992b). The following equation was used for calculation of apparent ileal or total tract digestibility of nutrients:

$$
\begin{aligned}
& \text { Digestibility }(\%) \\
& =100-[100 \times(\text { diet AIA \%/excreta or ileal digesta AIA \%) } \\
& \quad \times(\text { excreta or ileal digesta nutrient \%/diet nutrient \% })]
\end{aligned}
$$

\section{Free sugar measurement}

The concentrations of glucose, galactose, arabinose, xylose, mannose and ribose in the digesta samples were evaluated by using gas chromatography (GC). This was modified from the method of Quigley et al. (1999) as follows.

The standards of glucose (Sigma G7021), arabinose (Sigma A3131), xylose (Sigma X1500), galactose (Fluka
48260), mannose (Fluka 63580) and ribose (Sigma R7500) were purchased from Sigma-Aldrich Co., St. Louis, MO, USA. All of them were dried to constant mass, and were (a weight of $200 \mathrm{mg}$ of each sugar standard) diluted to $200 \mathrm{~mL}$ with $50 \%$ saturated benzoic acid to obtain standard stock solutions at $1 \mathrm{mg} / \mathrm{mL}$ and then stored at $4{ }^{\circ} \mathrm{C}$ for preparing working sugar standards. Milli-Q water (Millipore, Milford, MA, USA) was used throughout. All other chemicals and solvents were of analytical reagent or gas chromatographic grade.

The freeze-dried digesta sample $(0.5 \mathrm{~g})$ was dissolved in $12.5 \mathrm{~mL} 80 \%(\mathrm{v}: \mathrm{v})$ ethanol. The tubes were then placed at 10 second intervals into an oscillating rack in a water bath maintained at $40^{\circ} \mathrm{C}$ for $1 \mathrm{~h}$. After centrifugation at $1,800 \times \mathrm{g}$ for $10 \mathrm{~min}, 2 \mathrm{~mL}$ of supernatant fraction was transferred to a new tube for $\mathrm{GC}$ analysis.

The monosaccharide contents in the reaction mixture were analyzed on a Shimadzu GC-14B gas chromatograph (Shimadzu Corp., Kyoto, Japan) equipped with a DB-225 capillary column $(30 \mathrm{~m} \times 0.25 \mathrm{~mm}$ id; J\&W Scientific Inc., Folsom, CA, USA) and a flame-ionization detector (FID). The column temperature was kept at $195^{\circ} \mathrm{C}$ for $2 \mathrm{~min}$, raised to $235^{\circ} \mathrm{C}$ at $15^{\circ} \mathrm{C} / \mathrm{min}$ and maintained at this temperature for $10 \mathrm{~min}$. The temperatures of the injector and detector were set at $300^{\circ} \mathrm{C}$. A volume of $1 \mu \mathrm{L}$ of sample was used for GC analysis.

\section{Oligosaccharide measurement}

The standards of isomaltose (Supelco 47268-U), isomaltotriose (DP3, Supelco 47884), panose (D-panose, Sigma P2047) and 1-kestose (Fluka 72555) were purchased from Sigma-Aldrich. The freeze-dried digesta sample $(0.5$ g) was oximated with $0.5 \mathrm{~mL}$ oximating agents (dissolving $5 \mathrm{~g}$ of hydroxylamine hydrochloride in $50 \mathrm{~mL}$ of pyridine) for $15 \mathrm{~min}$ at $60^{\circ} \mathrm{C}$ until dried, and then silylated with 0.5 $\mathrm{mL} \mathrm{N}$-(trimethylsilyl)imidazole for $5 \mathrm{~min}$. The reaction mixture is then neutralized with $0.2 \mathrm{~mL}$ ultrapure water and $0.4 \mathrm{~mL}$ isooctane. After centrifugation at $1,800 \times \mathrm{g}$ for 10 min, the upper organic phase was collected for oligosaccharide concentrations using GC analysis modified from Joye and Hoebregs (2000). The GC analyses were carried out on a Finnigan Trace GC 2000 equipped with a FID, using a HP-5 MS capillary column $(30 \mathrm{~m} \times 0.25 \mathrm{~mm}$ id, $0.25 \mu \mathrm{m})$. The GC-MS analysis was performed on a Finnigan Trace GC 2000 equipped with a Finnigan DSQ mass spectrometer, using the same column described above. The detailed experimental conditions were as follows: injection volume, $1 \mu \mathrm{L}$; injection temperature, $330^{\circ} \mathrm{C}$; detector temperature, $330^{\circ} \mathrm{C}$; column temperature programmed from 200 to $290^{\circ} \mathrm{C}$ at $5^{\circ} \mathrm{C} / \mathrm{min}$, holding for 5 min at $290^{\circ} \mathrm{C}$, then increasing to $310^{\circ} \mathrm{C}$ at $10^{\circ} \mathrm{C} / \mathrm{min}$ and finally holding for $3 \mathrm{~min}$ at $230^{\circ} \mathrm{C}$. Nitrogen was used as 
the carrier gas at a flow rate of $1.2 \mathrm{~mL} / \mathrm{min}$.

\section{Statistical analyses}

Data of growth performance and digestibility were performed by independent-sample t-test with SPSS statistical software (version 11.0 for Windows, SPSS Inc., Chicago, IL, USA). Data of the concentrations of free sugars and oligosaccharides in different sections of GIT were analyzed as a $2 \times 6$ factorial arrangement by a general llinear model procedure (SPSS 11.0). The variance model included the main effects of the xylanase supplemental level, sections of GIT and their interaction. The results were presented by mean values and the standard error of the mean (SEM). All statements of significance are considered on a p-value less than 0.05 .

\section{RESULTS}

\section{Growth performance}

The growth performance of broiler chickens fed diets containing xylanase from 7 to 21 days of age was present in Table 2. Xylanase supplementation significantly increased BWG of broiler at 21 day of age by $5.8 \%(\mathrm{p}<0.05)$ and improved FCR by $5.3 \%(\mathrm{p}<0.05)$ compared to those birds fed xylanase-free diets. No significant difference on feed intake was observed between treatments $(p>0.05)$.

\section{Digestibility}

As shown in Table 3, xylanase significantly increased ( $<<0.05$ ) ileal digestibilities of CP by $3.5 \%$, starch by $9.3 \%$, soluble NSP by $43.9 \%$ and insoluble NSP by $42.2 \%$ relative to the control group, respectively. Also, compared with the control treatment, xylanase addition increased $(\mathrm{p}<0.05)$ total tract digestibilities of DM by $5.7 \%, \mathrm{CP}$ by $4.1 \%$, starch by $6.3 \%$, soluble NSP by $50.8 \%$, and had a tendency to increase ( $\mathrm{p}=0.093$ ) insoluble NSP by $19.9 \%$, respectively. The ileal and total tract digestibilities of fat and ash, as well as ileal DM digestibility was not affected by xylanase supplementation $(\mathrm{p}>0.05)$.

\section{Concentrations of free sugars and some oligosaccharides in digesta \\ Xylanase addition increased the concentrations of}

Table 2. Effects of xylanase supplementation on growth performance of broilers fed wheat-based diet

\begin{tabular}{lcccc}
\hline Items & Control & Xylanase & SEM & p-value \\
\hline Initial BW (g/bird) & 122.3 & 122.5 & 0.74 & 0.982 \\
7 to 21 days & & & & \\
$\quad$ BW gain (g/bird) & 498.9 & 528.4 & 4.91 & 0.029 \\
Feed intake (g/bird) & 798.2 & 803.2 & 12.95 & 0.953 \\
FCR & 1.60 & 1.52 & 0.03 & 0.048 \\
\hline
\end{tabular}

SEM, standard error of the mean; BW, body weight; FCR, feed conversion ratio (feed:gain, $\mathrm{g}: \mathrm{g}$ ).
Table 3. Effects of xylanase supplementation on ileal and total tract apparent digestibility of nutrients and NSP in broilers fed wheat-based diet

\begin{tabular}{lcccc}
\hline Items & Control & Xylanase & SEM & p-value \\
\hline \multicolumn{1}{l}{ Ileal apparent digestibility $(\%)$} & & & \\
DM & 61.1 & 63.9 & 1.05 & 0.191 \\
CP & 60.6 & 62.7 & 0.53 & 0.041 \\
Fat & 62.6 & 65.9 & 0.93 & 0.130 \\
Starch & 74.0 & 80.9 & 1.16 & 0.018 \\
Ash & 24.8 & 22.3 & 0.90 & 0.883 \\
Soluble NSP & 18.9 & 27.2 & 1.35 & 0.037 \\
Insoluble NSP & 19.2 & 27.3 & 0.99 & 0.022 \\
Total tract apparent digestibility $(\%)$ & & \\
DM & 72.5 & 76.6 & 0.95 & 0.015 \\
CP & 61.5 & 64.0 & 0.59 & 0.021 \\
Fat & 66.0 & 67.1 & 0.63 & 0.282 \\
Starch & 81.5 & 86.6 & 1.02 & 0.045 \\
Ash & 36.9 & 38.1 & 1.25 & 0.762 \\
Soluble NSP & 43.3 & 65.3 & 1.85 & $<0.001$ \\
Insoluble NSP & 33.2 & 39.8 & 1.43 & 0.093 \\
\hline
\end{tabular}

NSP, non-starch polysaccharides; SEM, standard error of the mean; DM, dry matter; $\mathrm{CP}$, crude protein.

arabinose and xylose in the digesta of gizzard, duodenum, jejunum and ileum $(\mathrm{p}<0.05$, Table 4$)$, and the order of their concentration was ileum $>$ jejunum $>$ duodenum $>>$ gizzard $>$ caecum. Interactions between xylanase supplemental level and sections of GIT on concentrations of arabinose and xylose were observed $(\mathrm{p}<0.05)$. No significant differences in the concentrations of ribose, mannose, galactose and glucose in digesta samples of all the GIT sections was observed between treatments $(p>0.05)$. The concentrations of all these 5 kinds of free sugars were lowest in the caecal digesta.

No significant effect was found in the concentrations of isomaltose, panose, and 1-kestose in digesta samples of all the GIT sections between treatments ( $p>0.05$, Table 4). Ileal isomaltriose concentration was higher in birds fed the diet supplemented with xylanase compared to the control diet $(\mathrm{p}<0.05)$, and the order of its concentration was jejunum $>$ duodenum $>$ ileum.

\section{DISCUSSION}

In accordance with previous reports (Gao et al., 2007; 2008; Esmaeilipour et al., 2011), the data of the present study once more confirmed that the addition of xylanase to wheat-based diets significantly increased the BWG and improved the FCR of broilers at 21 day of age. In this study, xylanase supplementation did not affect the feed intake of birds, indicating that the improvement in feed efficiency observed is likely to be a result of the improved nutrient utilization. 
Table 4. Effects of xylanase supplementation on the concentrations of free sugars and some oligosaccharides (mg/g as received) in different sections of the gastrointestinal tract of broilers fed wheat-based diet

\begin{tabular}{|c|c|c|c|c|c|c|c|c|c|c|}
\hline & \multicolumn{6}{|c|}{ Monosaccharide concentrations } & \multicolumn{4}{|c|}{ Oligosaccharide concentrations } \\
\hline & Ribose & Arabinose & Xylose & Mannose & Galactose & Glucose & Isomaltose & Panose & Isomaltriose & 1-Kestose \\
\hline \multicolumn{11}{|l|}{ Crop } \\
\hline Control & $0.27^{\mathrm{bc}}$ & $0.37^{\mathrm{f}}$ & $0.42^{\mathrm{f}}$ & $6.12^{\mathrm{b}}$ & $0.13^{\mathrm{c}}$ & $2.63^{\mathrm{d}}$ & $0.15^{\mathrm{c}}$ & $0.07^{\mathrm{d}}$ & $0.14^{\mathrm{d}}$ & $0.15^{\mathrm{e}}$ \\
\hline Xylanase & $0.23^{\mathrm{c}}$ & $0.63^{\mathrm{ef}}$ & $0.72^{\mathrm{f}}$ & $6.18^{\mathrm{b}}$ & $0.21^{\mathrm{bc}}$ & $2.64^{\mathrm{d}}$ & $0.17^{\mathrm{c}}$ & $0.10^{\mathrm{d}}$ & $0.20^{\mathrm{d}}$ & $0.18^{\mathrm{e}}$ \\
\hline \multicolumn{11}{|l|}{ Gizzard } \\
\hline Control & $0.22^{\mathrm{c}}$ & $0.42^{\mathrm{f}}$ & $0.55^{\mathrm{f}}$ & $6.33^{\mathrm{b}}$ & $0.25^{\mathrm{ab}}$ & $2.71^{\mathrm{d}}$ & $0.13^{\mathrm{c}}$ & $0.09^{\mathrm{d}}$ & $0.18^{\mathrm{d}}$ & $0.13^{\mathrm{e}}$ \\
\hline Xylanase & $0.29^{\mathrm{bc}}$ & $0.85^{\mathrm{de}}$ & $1.19^{\mathrm{de}}$ & $6.20^{\mathrm{b}}$ & $0.23^{\mathrm{b}}$ & $2.74^{\mathrm{d}}$ & $0.10^{\mathrm{c}}$ & $0.15^{\mathrm{d}}$ & $0.17^{\mathrm{d}}$ & $0.14^{\mathrm{e}}$ \\
\hline \multicolumn{11}{|l|}{ Duodenum } \\
\hline Control & $0.33^{\mathrm{ab}}$ & $0.65^{\mathrm{ef}}$ & $1.01^{\mathrm{e}}$ & $6.12^{\mathrm{b}}$ & $0.31^{\mathrm{a}}$ & $22.95^{\mathrm{b}}$ & $1.79^{\mathrm{a}}$ & $1.37^{\mathrm{b}}$ & $0.42^{\mathrm{c}}$ & $0.37^{\mathrm{cd}}$ \\
\hline Xylanase & $0.31^{\mathrm{b}}$ & $1.18^{\mathrm{bc}}$ & $1.54^{\mathrm{cd}}$ & $6.27^{\mathrm{b}}$ & $0.29^{\mathrm{ab}}$ & $23.37^{\mathrm{b}}$ & $1.80^{\mathrm{a}}$ & $1.22^{\mathrm{b}}$ & $0.48^{\mathrm{c}}$ & $0.52^{\mathrm{bc}}$ \\
\hline \multicolumn{11}{|l|}{ Jejunum } \\
\hline Control & $0.32^{\mathrm{ab}}$ & $1.08^{\mathrm{cd}}$ & $1.44^{\mathrm{cd}}$ & $7.39^{\mathrm{a}}$ & $0.33^{\mathrm{a}}$ & $50.81^{\mathrm{a}}$ & $2.14^{\mathrm{a}}$ & $2.41^{\mathrm{a}}$ & $1.14^{\mathrm{ab}}$ & $0.57^{\mathrm{ab}}$ \\
\hline Xylanase & $0.37^{\mathrm{a}}$ & $1.49^{\mathrm{b}}$ & $1.93^{\mathrm{b}}$ & $7.47^{\mathrm{a}}$ & $0.31^{\mathrm{a}}$ & $51.80^{\mathrm{a}}$ & $2.22^{\mathrm{a}}$ & $2.15^{\mathrm{a}}$ & $1.25^{\mathrm{a}}$ & $0.65^{\mathrm{a}}$ \\
\hline \multicolumn{11}{|l|}{ Ileum } \\
\hline Control & $0.35^{\mathrm{a}}$ & $1.37^{\mathrm{b}}$ & $1.66^{\mathrm{bc}}$ & $8.01^{\mathrm{a}}$ & $0.32^{\mathrm{a}}$ & $10.07^{\mathrm{c}}$ & $1.13^{\mathrm{b}}$ & $1.55^{\mathrm{b}}$ & $0.90^{\mathrm{b}}$ & $0.32^{\mathrm{d}}$ \\
\hline Xylanase & $0.38^{\mathrm{a}}$ & $2.71^{\mathrm{a}}$ & $2.94^{\mathrm{a}}$ & $7.90^{\mathrm{a}}$ & $0.35^{\mathrm{a}}$ & $12.10^{\mathrm{c}}$ & $0.90^{\mathrm{b}}$ & $1.43^{\mathrm{b}}$ & $1.25^{\mathrm{a}}$ & $0.40^{\mathrm{cd}}$ \\
\hline \multicolumn{11}{|l|}{ Caecum } \\
\hline Control & $0.24^{\mathrm{c}}$ & $0.58^{\mathrm{ef}}$ & $0.58^{\mathrm{f}}$ & $0.43^{\mathrm{c}}$ & $0.10^{c}$ & $1.21^{\mathrm{e}}$ & $0.36^{\mathrm{c}}$ & $0.62^{\mathrm{c}}$ & $0.29^{\mathrm{d}}$ & $0.07^{\mathrm{e}}$ \\
\hline Xylanase & $0.23^{\mathrm{c}}$ & $0.57^{\mathrm{ef}}$ & $0.55^{\mathrm{f}}$ & $0.44^{\mathrm{c}}$ & $0.13^{\mathrm{c}}$ & $1.29^{\mathrm{e}}$ & $0.32^{\mathrm{c}}$ & $0.60^{\mathrm{c}}$ & $0.36^{\mathrm{cd}}$ & $0.06^{\mathrm{e}}$ \\
\hline Pooled SEM & 0.03 & 0.17 & 0.24 & 0.60 & 0.05 & 3.70 & 0.18 & 0.17 & 0.09 & 0.04 \\
\hline \multicolumn{11}{|l|}{ p-value } \\
\hline Sections of GIT & 0.012 & $<0.001$ & $<0.001$ & $<0.001$ & 0.015 & $<0.001$ & $<0.001$ & $<0.001$ & $<0.001$ & $<0.001$ \\
\hline Xylanase & 0.630 & 0.036 & 0.020 & 0.992 & 0.951 & 0.954 & 0.912 & 0.573 & 0.901 & 0.794 \\
\hline $\begin{array}{l}\text { Sections of GIT } \\
\times \text { Xylanase }\end{array}$ & 0.685 & 0.021 & 0.043 & 0.966 & 0.873 & 0.407 & 0.259 & 0.493 & 0.996 & 0.895 \\
\hline
\end{tabular}

SEM, standard error of the mean; GIT, gastrointestinal tract.

Means within a column with no common superscripts differ significantly.

It is well recognized that water-soluble arabinoxylans are major anti-nutritive factors of NSP in wheat-based diets, which increase digesta viscosity, enclose nutrients, modulate gut microflora and, thus, interfere with digestion and absorption of the nutrients (Choct and Annison, 1992a; Choct et al., 1996). The present study demonstrated that addition of xylanase to wheat-based diet has the capacity to increase ileal and total tract digestibilities of $\mathrm{CP}$ and starch (Table 3), which could be the direct reason for the improvement of growth performance in broilers. Our results are partially consistent with the findings of Esmaeilipour et al. (2012) who reported that xylanase significantly decreased the viscosity of digesta and improved apparent total tract nutrient digestibilities of DM, CP and energy in broiler chickens fed wheat-based diets from 1 to 24 days of age. In a previous study, Gao et al. (2007) reported that the addition of xylanase to wheat-based diet increased the apparent total tract digestibility of fat. However, no significant effect of xylanase on both ileal and total tract digestibilities of fat were observed in this study, which is in accordance with several previous studies (Bedford, 2000; Esmaeilipour et al., 2012). Therefore, the present findings, along with those results from Bedford (2000) and Esmaeilipour et al. (2012), suggest that xlyanase can reduce nutrient entrapment and increase their digestibilities, mostly starch and protein rather than fat.

The cell walls of cereals contain up to 15\% NSP, which are comprised of soluble and insoluble NSP (Diebold et al., 2004). The insoluble fraction of NSP makes up the bulk of the total fibre in diets, and they are traditionally regarded as a nutrient dilution agent and have little or no effect on nutrient utilization in monogastric animals (Choct, 1997; Hetland et al., 2004). However, the soluble fraction of NSP, mainly arabinoxylans in wheat, can not only act as a physical barrier to nutrient digestion and absorption by increasing gut viscosity, but also change digestive tract functions by modifying secretion of endogenous digestive enzymes, water, and electrolytes, as well as elevating fermentation in the small intestine (Choct 1996; Choct et al., 1997). In a recent study, Barekatain et al. (2013) reported that addition of xylanase to diets containing sorghum distillers' dried grains with soluble (sDDGS) significantly reduced the concentration of insoluble NSP, and increased the concentration of free sugars (arabinose and xylose) in 
the ileal digesta. They explained that the availability of these free sugars may have provided nutrients to the birds, leading to improved FCR. In the present study, addition of xylanase to wheat-based diet significantly increased the ileal and total tract digestibilities of both soluble and insoluble NSP. Therefore, it can be concluded that exogenous xylanase eliminates the anti-nutritive effect of NSP by partial hydrolysis of both soluble and in soluble NSP, which leads to the reduction of gut digesta viscosity, and the increase of nutrient digestibility. Moreover, the higher total tract digestibilities of both soluble and insoluble NSP than those in the ileal digesta may due mainly to the caecal fermentation.

The beneficial effects of feed xylanase are primarily the reduction in the viscosity and, secondarily, the release of sugars (Malathi and Devegowda, 2001; Choct et al., 2004; Barekatain et al., 2013). The release of monosaccharides caused by exogenous enzymes is due to two reasons: firstly, the breakdown of NSP led to release of their respective monosaccharides, and secondly, the breakdown of NSP released the starch within the endosperm, which was exposed to the endogenous amylase, releasing more glucose (Malathi and Devegowda, 2001). However, in the present study, no significant difference in digesta glucose concentrations of different sections of the GIT between treatments was found. We speculate that this phenomenon may be mainly because of the higher glucose absorption in broilers fed xylanase. Choct et al. (2004) reported that xylanases increased the amounts of free sugars by releasing the arabinose and xylose (the two main sugars of wheat arabinoxylans) both in the jejunal and the ileal digesta of birds fed a wheat-based diet. Xylanase also increases the concentrations of arabinose and xylose in the ileal digesta of birds fed a diet containing sDDGS (Barekatain et al., 2013). This study is the first to report the effect of xylanase on the release of sugars in the different sections of GIT of broilers. Our results showed that the addition of xylanase did not affect the digesta concentrations of ribose, mannose, galactose and glucose in all section of the GIT, but increased the concentrations of arabinose and xylose in the digesta of gizzard, duodenum, jejunum and ileum, and the order of their concentration was ileum>jejunum> duodenum $>>$ gizzard $>$ caecum (Table 4). These findings indicate that i) the monosaccharides released from wheat NSP mainly were arabinose and xylose hydrolyed form arabinoxylans, rather than ribose, mannose and galactose; and ii) the main site for arabinoxylans hydrolysis was the small intestine with the order of ileum $>$ jejunum $>$ duodenum.

A world-wide interest in oligosaccharides is on the increase because of their potential prebiotic function (Patel and Goyal, 2011). Fructo-oligosaccharides, such as 1kestose, nystose and fructosylnystose, are nondigsetable, but they are selectively utilized by the resident microbes, such as lactic acid bacteria and Bifidobacteria in the gut (Kaplan and Hutkins, 2000; Parracho et al., 2007). Isomalto-oligosaccharides, including isomaltose, panose and isomaltotetraose, have been demonstrated to normalize bowel movement, increase stool bulk, stimulate colon microbial activity (i.e., the growth of Bifidobacteria and Lactobacillus), and modulate the immune function (Chen et al., 2001; Hirayama, 2002; Chung and Day, 2004). In the present study, no significant difference on the concentrations of isomaltose, panose and 1-kestose was observed between treatments, except for a higher ileal isomaltriose concentration in birds fed with xylanase, indicating that the growth-promoting effect of xylanase is not due to increased concentrations of these potentially prebiotic oligosaccharides.

\section{CONCLUSIONS}

The supplementation of xylanase to wheat-based diets cuts the arabinoxylan backbone into small fragments (mainly arabinose and xylose) in the ileum, jejunum and duodenum, and enhances digestibilites of nutrients by decreasing digesta viscosity. Although dietary xylanase did not affect the concentrations of some potentially prebiotic oligosaccharides, including isomaltose, panose and 1kestose, in the GIT, the release of arabinose and xylose in the small intestine may also be the important contributors to the growth-promoting effect of xylanase in broilers fed wheat-based diets.

\section{ACKNOWLEDGMENTS}

This study was supported by the National Natural Science Foundation of China (30300251) and Three Agricultural Projects of Jiangsu province of China (SX(2011)146).

\section{REFERENCES}

AOAC. 2000. Official Methods of Analysis, 17th ed. Association of Official Analytical Chemists, Arlington, VA, USA.

Bailey, M. J. 1988. A note on the use of dinitrosalicylic acid for determining the products of enzymatic reactions. Appl. Microbiol. Biotechnol. 29:494-497.

Barekatain, M. R., C. Antipatis, M. Choct, and P. A. Iji. 2013. Interaction between protease and xylanase in broiler chicken diets containing sorghum distillers' dried grains with soluble. Anim. Feed Sci. Technol. 182:71-81.

Bedford, M. R. 2000. Exogenous enzymes in monogastric nutrition-their current value and future benefits. Anim. Feed Sci. Technol. 86:1-13.

Bedford, M. R. and H. L. Classen. 1992. Reduction of intestinal viscosity through manipulation of dietary rye and pentosanase 
concentration is effected through changes in the carbohydrate composition of the intestinal aqueous phase and results in improved growth rate and food conversion efficiency of broiler chicks. J. Nutr. 122:560-569.

Chen, H. L., H. O. Lu, J. J. Lin, and L. Y. Ko. 2001. Effects of isomalto- oligosaccharides on bowel functions and indicators of nutritional status in constipated elderly men. J. Am. Coll. Nutr. 20:44-49.

Choct, M. 1997. Feed non-starch polysaccharides: Chemical structures and nutritional significance. Feed Milling Int. 13-26.

Choct, M. and G. Annison. 1992a. Anti-nutritive effect of wheat pentosans in broiler chickens: Roles of viscosity and gut microflora. Br. Poult. Sci. 33:821-834.

Choct, M. and G. Annison. 1992b. The inhibition of nutrient digestion by wheat pentosans. Br. J. Nutr. 67:123-132.

Choct, M., A. Kocher, D. L. E. Waters, D. Pettersson, and G. Ross. 2004. A comparison of three xylanases on the nutritive value of two wheats for broiler chickens. Br. J. Nutr. 92:53-61.

Choct, M., R. J. Hughes, and M. R. Bedford. 1999. Effects of a xylanase on individual bird variation, starch digestion throughout the intestine, and ileal and caecal volatile fatty acid production in chickens fed wheat. Br. Poult. Sci. 40:419-422.

Choct, M., R. J. Hughes, J. Wang, M. R. Bedford, A. J. Morgan, and G. Annison. 1996. Increased small intestinal fermentation is partly responsible for the anti-nutritive activity of non-starch polysaccharides in chickens. Br. Poult. Sci. 37:609-621.

Chung, C. H. and D. F. Day. 2004. Efficacy of Leuconostoc mesenteroides (ATCC 13146) isomaltooligosaccharides as a poultry prebiotic. Poult. Sci. 83:1302-1306.

Diebold, G., R. Mosenthin, H. P. Piepho, and W. C. Sauer. 2004. Effect of supplementation of xylanase and phospholipase to a wheat-based diet for weanling pigs on nutrient digestibility and concentrations of microbial metabolites in ileal digesta and feces. J. Anim. Sci. 82:2647-2656.

Englyst, H. N., M. E. Quigley, and G. J. Hudson. 1994. Determination of dietary fibre as non-starch polysaccharides with gas-liquid chromatographic, high-performance liquid chromatographic or spectrophotometric measurement of constituent sugars. Analyst 119:1497-1509.

Esmaeilipour, O., H. Moravej, M. Shivazad, M. Rezaian, S. Aminzadeh, and M. M. Van Krimpen. 2012. Effects of diet acidification and xylanase supplementation on performance, nutrient digestibility, duodenal histology and gut microflora of broilers fed wheat based diet. Br. Poult. Sci. 53:235-244.

Esmaeilipour, O., M. Shivazad, H. Moravej, S. Aminzadeh, M. Rezaian, and M. M. Van Krimpen. 2011. Effects of xylanase and citric acid on the performance, nutrient retention, and characteristics of gastrointestinal tract of broilers fed lowphosphorus wheat-based diets. Poult. Sci. 90:1975-1982.

Friesen, O. D., W. Guenter, R. R. Marquardt, and B. A. Rotter. 1992. The effect of enzyme supplementation on the apparent metabolizable energy and nutrient digestibilities of wheat, barley, oats and rye for young broiler chicks. Poult. Sci. 71:1710-1721.

Gao, F., Y. Jiang, G. H. Zhou, and Z. K. Han. 2007. The effects of xylanase supplementation on growth, digestion, circulating hormone and metabolite levels, immunity and gut microflora in cockerels fed on wheat-based diets. Br. Poult. Sci. 48:480488.3 .
Gao, F., Y. Jiang, G. H. Zhou, and Z. K. Han. 2008. The effects of xylanase supplementation on performance, characteristics of the gastrointestinal tract, blood parameters and gut microflora in broilers fed on wheat-based diets. Anim. Feed Sci. Technol. 142:173-184.

Hetland, H., M. Choct, and B. Svihus. 2004. Role of insoluble non-starch polysaccharides in poultry nutrition. World's Poult. Sci. J. 60:415-422.

Hirayama, M. 2002. Novel physiological functions of oligosaccharides. Pure Appl. Chem. 74:1271-1279.

Joye, D. and H. Hoebregs. 2000. Determination of oligofructose, a soluble dietary fiber, by high-temperature capillary gas chromatography. J. AOAC Int. 83:1020-1026.

Kaplan, H. and R. W. Hutkins. 2000. Fermentation of fructooligosaccharides by lactic acid bacteria and bifidobacteria. Appl. Environ. Microbiol. 66:2682-2684.

Liu, D., S. S. Guo, and Y. M. Guo. 2012. Xylanase supplementation to a wheat-based diet alleviated the intestinal mucosal barrier impairment of broiler chickens challenged by Clostridium perfringens. Avian Pathol. 41:291-298.

Malathi, V. and G. Devegowda. 2001. In vitro evaluation of nonstarch polysaccharide digestibility of feed ingredients by enzymes. Poult.Sci. 80:302-305.

McCleary, B. V., T. S. Gibson, and D. C. Mugford. 1997. Measurement of total starch in cereal products by amyloglucosidase- $\alpha$-amylase method: Collaborative study. J. Assoc. Off. Anal. Chem. 80:571-579.

Meng, X., B. A. Slominski, C. M. Nyachoti, L. D. Campbell, and W. Guenter. 2005. Degradation of cell wall polysaccharides by combinations of carbohydrase enzymes and their effect on nutrient utilization and broiler chicken performance. Poult. Sci. 84:37-47.

Nian, F., Y. M. Guo, Y. J. Ru, F. D. Li, and A. Péron. 2011. Effect of exogenous xylanase supplementation on the performance, net energy and gut microflora of broiler chickens fed wheatbased diets. Asian Australas. J. Anim. Sci. 24:400-406.

Parracho, H., A. L. McCartney, and G. R. Gibson. 2007. Probiotics and prebiotics in infant nutrition. Proc. Nutr. Soc. 66:405-411.

Patel, S. and A. Goya. 2011. Functional oligosaccharides: production, properties and application. World J. Microbiol. Biotechnol. 27:1119-1128.

Quigley, M. E., G. J. Hudson, and H. N. Englyst. 1999. Determination of resistant short-chain carbohydrates (nondigestible oligosaccharides) using gas-liquid chromatography. Food Chem. 65:381-390.

Vandeplas, S., R. D. Dauphin, C. Thiry, Y. Beckers, G. W. Welling, P. Thonart, and A. Théwis. 2009. Efficiency of a Lactobacillus plantarum-xylanase combination on growth performances, microflora populations, and nutrient digestibilities of broilers infected with Salmonella Typhimurium. Poult. Sci. 88:16431654.

Vandeplas, S., R. D. Dauphin, P. Thonart, A. Théwis, and Y. Beckers. 2010. Effect of the bacterial or fungal origin of exogenous xylanases supplemented to a wheat-based diet on performance of broiler chickens and nutrient digestibility of the diet. Can. J. Anim. Sci. 90:221-228.

Vogtmann, H., P. Frirter, and A. L. Prabuck. 1975. A new method of determining metabolizability of energy and digestibility of fatty acids in broiler diets. Br. Poult. Sci. 16:531-534. 